\title{
A GEOCHEMICAL CLASSIFICATION OF DIKES OF THE GRANDE RONDE SWARM, COLUMBIA RIVER BASALT
}

\author{
Susan M. Price
}

\begin{abstract}
Physical and Life Science Technology Section Research Department Research and Engineering Division
\end{abstract}

May 1974

This report was prepared as an account of work This report wates Government. Neither sponsored by the United States nor the United States Energy the United States nor the United States Energy Research and Development Administration, nor any of their employees, nor any of their contractors, subcontractors, or their employees, makes any warranty, express or implied, or assumes any legal liability or responsibility for the accuracy, completeness labilty or resp any information, apparatus, product or or usefulness of any information, apparatus, product oo process disclosed, or represents
infringe privately owned rights.

\section{ATLANTIC RICHFIELD HANFORD COMPANY \\ RICHLAND, WASHINGTON 99352}

Partial text of a paper presented at the Annual Meeting of the Geological Society of. America November 12-14, 1973

Dall las, Texas 


\section{DISCLAIMER}

This report was prepared as an account of work sponsored by an agency of the United States Government. Neither the United States Government nor any agency Thereof, nor any of their employees, makes any warranty, express or implied, or assumes any legal liability or responsibility for the accuracy, completeness, or usefulness of any information, apparatus, product, or process disclosed, or represents that its use would not infringe privately owned rights. Reference herein to any specific commercial product, process, or service by trade name, trademark, manufacturer, or otherwise does not necessarily constitute or imply its endorsement, recommendation, or favoring by the United States Government or any agency thereof. The views and opinions of authors expressed herein do not necessarily state or reflect those of the United States Government or any agency thereof. 


\section{DISCLAIMER}

Portions of this document may be illegible in electronic image products. Images are produced from the best available original document. 


\section{ABSTRACT}

Analysis of approximately 40 major Columbia River Basalt dikes of the Grande Ronde swarm, northeastern oregonsoutheastern Washington, revealed that these dikes can be divided into six chemical classes. The compositions of dikes of four of these classes are comparable with the Yakima, Umatizia, Lolo, and.Frenchmen Springs chemical types of wright and others (1973). The dikes of the remaining two classes have an average content of $47.4 \% \mathrm{SiO}_{2}, 10.3 \% \mathrm{CaO}$, $1.7 \% \mathrm{TiO}_{2}, 0.49 \% \mathrm{~K}_{2} \mathrm{O}$, and $7.9 \% \mathrm{MgO}$; and $51.5 \% \mathrm{SiO}_{2}, 9.5 \%$ $\mathrm{CaO}, 1.4 \% \mathrm{TiO}_{2}, 0.75 \% \mathrm{~K}_{2} \mathrm{O}$, and $5.8 \% \mathrm{MgO}$.

- Analysis of Columbia River Basalt flows of the swarm area disclosed that lower yakima flows (as defined by wright and others, 1973) are chemically comparable to dikes of yakima-type chemistry and that middie yakima flows are chemically. comparable to dikes of one of the remaining five classes. The dike-flow relations indicated by chemistry can be substantiated by fieid evidence.

The study revealed that several flows and related dikes of the Grande Ronde area are chemically equivalent to Pasco Basin flows characterized by the Atlantic Richfield Hanford Company. This observation supports the need to direct further work toward ascertaining the extent to which chemically similar flows in both areas can be correlated in the. fieid. Such a study would afford a more adequate evaluation of the significance of the Grande Ronde dike sirarm as a source area. 
A GEOCHEMICAL . CLASSIFICATION OF DIKES OF THE GRANDE RONDE SWARM, COLUMBIA RIVER. BASALT

\author{
INTRODUCTION
}

In 1968 the Atlantic Richfield Hanford Company (ARHCO), in behalf of the United States Atomic Energy. Commission, undertook a study to develop a detailed stratigraphic model of the Columbia River Basalt flows underlying the Pasco Basin. The ensuing effort was directed toward the drilling of five deep core wells and a comprehensive geochemical characterization of the basalt flows penetrated. The results of this work showed conclusively that certain flows. exhibit unique chemical properties that do not vary significantly with distances of up to $40 \mathrm{~km}$ (Brown and Ledgerwood, 1973, p. 174) and underscored the feasibility of utilizing comparative geochemistry for long-distance correlation.

Possible source areas for many of the flows underlying the Pasco Basin are major denuded dike swarms bordering the margins of the Columbia Plateau. When a need was expressed by ARHCO to define the relation of distal swarms (Fig. I) to flows of the Basin, an examination of the Grande Ronde dike swarm was initiated ${ }^{1}$. The subsequent investigation was oriented toward determining the feasibility of utilizing comparative geochemistry to indicate dike-flow correla.tions.

This document is an account of the initial results of this investigation and is predominantly concerned with the

${ }^{1}$ Supported by the U. S. Atomic Energy Commission, Contract No: AT (45-1)-2042, while on, a Northwest College and University Association for Science Appointment, July 1972 through september 1973 . 
geochemical classification of the dikes examined. The relation of the dikes to proximate Columbia River Basalt flows and to flows of the Pasco Basin will be discussed only briefly and will be covered in more detail in another publication now in preparation.

\section{AREA OF INVESTIGATION}

Flow-directional and petrographic studies (Waters, 1950, 1961; Schmincke, 1967; and Taubeneck, 1970) have indicated that many of the Columbia River Basalt flows of the central and eastern portions of the Plateau were sourced by dikes of the extensive Chief Joseph swarm (Taubeneck, 1970), formerly segregated by Waters (1961) into the Grande RondeCornucopia swarms. Few dikes of the Chief Joseph swarm are as well exposed as those traversing the canyons cut by the Grande Ronde River and its tributaries in northeastern Oregon and southeastern Washington (Fig. 1). A reconnaissance map (Fig. 2) published in 1969 by Gibson reveals the presence of approximately 40 major dikes in this area. The geochemical classification of these dikes is the subject of this paper.

\section{METHOD OF INVESTIGATION}

The major dikes mapped by Gibson (1969) were systematically sampled. To rapidly determine the degree to which the dikes could be chemically distinguished, all samples were analyzed for $\mathrm{CaO}, \mathrm{TiO}_{2}$, and $\mathrm{Ba}$ utilizing nondispersive $X$-ray fluorescence (NXRF). Analysis by NXRF indicated that a significant geochemical pattern was emerging, and subsequently composite samples of the dikes were analyzed by atomic absorption and by neutron activation to obtain a more complete chemical characterization. Thin-sections of 
selected samples were also examined to determine the degree to which the chemical variability was reflected petrographically.

\section{GEOCHEMICAL CLASSIFICATION OF DIKES OF THE GRANDE RONDE SWARM}

\section{PRESENTATION OF DATA}

Chemically, the dikes can be divided into six classes. ${ }^{2}$ Dikes belonging to four of these classes are closely comparable in composition to one of the 11 chemical types ${ }^{3}$ established by Wright and others (1973), and where applicable are designated as such. A discussion of the chemical and petrographic properties distinctiv of each of the six classes follows, concluded by a comparative summary.

\section{Class 1}

of the approximately 40 dikes sampled, the greatest number fall into the first chemical class. Chemically, members of this class (Fig. 3), with an average content of $54.0 \% \mathrm{SiO}_{2}, 7.3 \% \mathrm{CaO}, 1.9 \% \mathrm{TiO}_{2}, 1.5 \% \mathrm{~K}_{2} \mathrm{O}$, and $3.8 \% \mathrm{MgO}$, correspond to the Yakima chemical type of Wright and others (1973). Major, minor, and selected trace element analyses of three dikes belonging to this class are listed in Table $1-A$.

\footnotetext{
2 The term "class" (Price, 1973a) refers to an informal chemical grouping of dikes and flows of the Grande Ronde area which may possibly be correlatable. Only the dikes of each class are discussed in this section.

${ }^{3}$ The 11 chemical types of wright and others (1973) represent the compositions of volumetrically important columbia River Basalt flows or flow sequences. If chemically comparable, the types may be used to describe the composition of any dike (Wright and others, 1973, p. 381) or flow (wright and others, 1973, p. 376) regardless of "stratigraphic" position.
} 
Dikes of this class are incistinguislable pet ographically. Hand-specimen samples are characteristically dense and fine-grained, rarely displaying phenocryst.s. Samples in thin-section exhibit an intersertal texture with plagioclase and pyroxene microphenocrysts and microlites enclo:ied in a matrix of tachylite. A modal analysis of a dike petrographically representative of this class is presented in Table l-B.

Class 2

Dikes belonging to the second chemicel class are designated in Figure 3. Members of this class contain an average of $47.4 \% \mathrm{SiO}_{2}, 10.3 \% \mathrm{CaO}, 1.7 \% \mathrm{TiO}_{2}, 0.49 \% \mathrm{~K}_{2} \mathrm{O}$, and $7.9 \% \mathrm{MgO}$. The average composition cannot be adequately described by any of the chemical types of Wright a ld others (1973). Major, minor; and selected trace element zrialyses of two members of this class are listed in Table 2-A.

Petrographically, members of this class are generally medium- to coarse-grained in handspecimen. Thin-section specimens are holocrystalline and generally exhibit a diabasic texture. Olivine and olivine alteration prcaucts are characteristically present. A modal analysis of a dike petrographically representative of this class is presented in Table 2-B.

\section{Class 3}

Dikes belonging to the third chemical class are located in Figure 3. Members of this class contain an average. of $51.5 \% \mathrm{SiO}_{2}, 9.5 \% \mathrm{CaO}, 1.4 \% \mathrm{TiO}_{2}, 0.75 \% \mathrm{~K}_{2} \mathrm{O}$, and $5.8 \% \mathrm{MgO}$. The average composition of dikes of this class cannot be adequately described by any of the chemical types of wright and others (1973). Major, minor, and selected trace element analyses of two members of this class are listed in Table 3-A. 
Members of this class are generally medium- to coarsegrained in handspecimen. Thin-section specimens are generally holocrystalline and exhibit an ophitic or subophitic texture. Olivine or alteration products derived from olivine are generally present. A modal analysis of a dike petrographically characteristic of this class is listed in Table 3-B.

\section{Class 4}

The fourth chemical class contains only one dike (Fig: 3) chemically characterized by $54.3 \% \mathrm{SiO}_{2}, 6.0 \% \mathrm{C}$ $2.5 \% . \mathrm{TiO}_{2}, 2.6 \% \mathrm{~K}_{2} \mathrm{O}$, and $2.7 \% \mathrm{MgO}$. The chemistry of, this dike, listed in Table 4-A, corresponds closely to the Umatilla chemical type of Wright and others (1973).

Handspecimen samples of this dike are fine- to mediumgrained, exhibiting sparse phenocrysts of plagioclase up to $3 \mathrm{~mm}$ in length and blebs of chlorophaeite (Peacock and Fuller, 1928, p. 361) up to $2.5 \mathrm{~cm}$ in diameter. Thinsection samples display an intersertal texture with microphenocrysts and microlites of plagioclase and pyroxene, cross-cut by needles of apatite, surrounded by a matrix of tachylite. A modal analysis of a sample from this dike is presented in Table 4-B.

\section{Class 5}

Class 5 contains a single dike (Fig. 3) chemically characterized by $43.6 \% \mathrm{SiO}_{2}, 8.8 \% \mathrm{CaO}, 2.9 \% \mathrm{TiO}_{2}, 0.96 \% \mathrm{~K}_{2} \mathrm{O}$, and $4.8 \% \mathrm{MgO}$. The chemistry of this dike most closely resembles the Lolo chemical type of Wright and others (1973). A more complete analysis of this dike is listed in Table 5-A. 
Handspecimen samples of this dike are medium- to coarsegrained. Thin-section samples are holocrystalline, exhibiting a diabasic intergrowth of crystais of plagioclase, pyroxene, and altered olivine. A modal analysis of this dike is presented in Table 5-B.

\section{Class 6}

The sixth chemical class also contains only one member (Fig. 3). This dike averages $50.6 \% \mathrm{SiO}_{2}, 8.7 \% \mathrm{CaO}, 3.0 \%$ $\mathrm{TiO}_{2}, 1.3 \% \mathrm{~K}_{2} \mathrm{O}$, and $4.2 \% \mathrm{MgO}$, and most closely resembles in composition the Frenchmen springs chemical type of. Wright and others (1973). A more complete analysis of this ciike is listed in Table 6-A.

The dike of this class is porphyritic in handspecimen containing. 15 to $20 \%$ plagioclase phenocrysts averaging $5 \mathrm{~mm}$ in length. Thin-section samples exhibit an orthophyric texture with microphenocrysts and microlites of plagioclase and microlites of pyroxene surrounded by a tacylite matrix. A modal analysis of this dike is listed in Table $\epsilon-B$.

\section{COMPARATIVE SUMMARY}

The distinctive chemical composition of each class is best illustrated graphícally by $\mathrm{SiO}_{2}-\mathrm{MgO}, \mathrm{CaO}-\mathrm{MgO}$; $\mathrm{TiO}_{2}-\mathrm{MgO}$, and $\mathrm{K}_{2} \mathrm{O}-\mathrm{MgO}$ variation diagrams (Fig. 4). Each class, as illustrated in Table 7, also exhibits a characteristic range in content of selected trace elements. The referenced Figure and Table summarize most succinctly the intraclass and interclass chemical variations discussed in the text:

A summary of the petrographic properties distinctive of each class is presented in Table 8 . 


\section{DIKE-FLOW RELATIONS INDICATED BY GEOCHEMISTRY}

\section{RELATION OF DIKES TO PROXIMATE FLOWS}

Analysis of basalt flows comprising sections measured within the study area disclosed that the chemistry of the basalt pile varies in an orderly sequence. With reference to the informal stratigraphic classification of Wright and others (1973), the 1100-meter basalt section consists of approximately 80 meters of lower basalt, 900 meters of lower Yakima basalt, and 120 meters of section tentatively classified as middle Yakima basalt.

The chemistry of individual Yakima flows or flow sequences was found to be comparable to that of one of the six classes of dikes. Supplemental field work was oriented toward determining if chemically similar flows and dikes could also be related by field evidence. The subsequent examination revealed that dike-flow continuity is rarely preserved in the field and emphasized the value of utilizing comparative geochemistry to indicate dike-flow correliations (Price, 1973b). The relation of dikes of the six classes to proximate flows is summarized in Table 9.

\section{RELATION OF DIKES TO FLOWS OF THE PASCO BASIN}

A generalized stratigraphic column of the Columbia River basalt flows exposed around the margins of the Pasco Basin is presented in Figure 5. The unique flows identified by ARHCO in the deep core holes are essentially correlatable with members of this section (Ledgerwood, 1974, in press). The chemical composition of these flows can be described in general by 1 of the 11 chemical types of Wright and others (1973).

The data summarized in this document indicate that 
several of the flows and related dikes of the Grande Ronde area are chemically equivalent to flows of the Pasco Basin (see Fig.5). This finding supports the need for directing further work toward ascertaining the extent to which certain flows in both areas (especially those of Umatilla-type chemistry) can be correlated in the field. Before such a study is conducted, a statement concerning the relation of dikes of the Grande Ronde swarm to flows of similar composition in the Pasco Basin would be premature.

\section{REFERENCES CITED}

Brown, D. J., and Ledgerwood, R. K., 1973, Stratigraphy and structure of Yakima Basalt in Pasco Basin, Washington: in. Geologic Field Trips in Northern Oregon and Southern Washington, Oregon Department of Geology and Mineral. Industries, Bul1. 77, p. 171-181.

Gibson:, I. L., 1969, A comparative account of flood basalt $\because$ volcanism of the Columbia River Plateau and Eastern Iceland: Bull. Vocanol., v. 33, n. 2, p. 419-437..

Ledgerwood, R. K., 1974, Elemental variations in Columbia River Basalt flows underlying the Hanford Reservation: Atlantic Richfield Hanford Company, USAEC Report (in: press).

Ledgerwood, R. K., Brown, D. J., Waters, A. C., and Meyers, C. W., 1973, Identification of Yakima Basalt flows in the Pasco Basin: Atlantic Richfield Hanford Company, USAEC Report ARH-2768.

Peacock, M. A. and Fuller, R. E., 1928, Chlorophaeite, sideromelane, and palogonite from the Columbia River Plateau: Am. Mineralogist, v. 13, p. 360-382. 
Price, S. A.(M.), 1973a, A preliminary geochemical examination of the Grande Ronde dike swarm and proximate Yakima Basalt flows: Geol. Soc. America Abs. with Programs, v. 5, n. 1, p. 92 . , 1973b, Dike-flow relations indicated by - geochemistry, Grande Ronde dike swarm, Columbia River Basalt: Geol. Soc. America Abs. with Programs, v. 5, n. $7, \mathrm{p} .772$.

Schmincke, Hans-Ulrich, 1967, Stratigraphy and petrography of four upper Yakima Basalt flows in south-central Washington: Geol. Soc. America Bull., v. 78, p. 13851422 .

Taubeneck, W! H., 1970, Dikes of Columbia River Basalt in northeastern Oregon, western Idaho, and southeastern Washington: in Proceedings of Second Columbia River Basalt Symposium, Cheney, Washingtion, 1969, Eastern Washington State College Press, p. 73-96.

Waters, A. C., 1950, Multiple dike feeders of the Columbia River basalt (abs.): Geol. Soc. America Bull., v. 61, p. 1533 .

- 1961, stratigraphic and lithologic variations in the Columbia River basalt: Am. Jour. Sci., v. 259, p. 583-61i.

Wright, T. L. Grolier, M. J., and Swanson, D. A., 1973, Chemical variation related to the stratigraphy of the Columbia River basalt: Geol. Soc. America Bull., v. 84, n. 2 , p. $371-386$. 


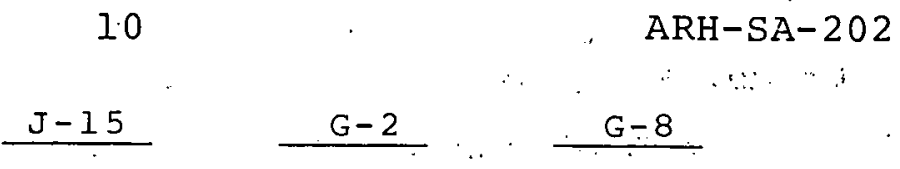

atomic absorption

8

$\mathrm{SiO}_{2}$
$\mathrm{Al}_{2} \mathrm{O}_{3}$
$\mathrm{FeO}$
$\mathrm{MgO}$
$\mathrm{CaO}$
$\mathrm{Na}_{2} \mathrm{O}$
$\mathrm{K}_{2} \mathrm{O}$
$\mathrm{MnO}^{\mathrm{TiO}_{2}}$
$\mathrm{P}_{2} \mathrm{O}_{5}$
$\mathrm{Volatility}$

Total

ppm

Cr
Ba

Ia

$\mathrm{Sm}$

$\mathrm{Yb}$

$\mathrm{Eu}$.

Co.

$\mathrm{SC}$

Hf

$\mathrm{Th}$

$\mathrm{Tb}$

Ta
54.5

13.7

11.5

5.1

8.8

2. 7

1.0

0.19

1. 7

0.3

0.9

100.4
54.5

13.7

12.4

3.3

7. 3

3.0

1. 6

0. 21

2.0

0.4

1. 2

99.6

17

822

50
591

neutron activation

18

4.7

2. 6

1.4

37

33

4. 0

4. 1

0.64

1. 9
24

5.1

5.1

1.8

38

33

6.2

5.3

1.0

5.0
$54 \cdot 3$

13.4

12.5

3.9 .

7.3

3.0

1.6

0.25

2.2 :

0.4

1. $2=$

100.0 .

*A1l Fe reported as Feo.

Table 1-A Chemical analyses of selected dikes from Class 1 (see Fig. 3) 
Minerals

Plagioclase

Pyroxene

Opaques

Glass

Decomposition products

Total

plagioclase/pyroxene ratio:

100-(glasstopaques)/pyroxene ratio:
Vol:

$$
\begin{array}{r}
42.6 \\
35.4 \\
8.3 \\
8.1 \\
5.6 \\
100.0 \\
1.2 \\
2.4
\end{array}
$$

Table 1-B Modal analysis of member (dike G-2) of class 1. Volume percentage of mineral constituents determined. from average of two sets of 500 point counts 
$\frac{J-16}{\text { atomic absorption }}$

웅

\begin{tabular}{|c|}
\hline $\mathrm{SiO}_{2}$ \\
\hline $\mathrm{Al}_{2} \mathrm{O}_{3}$ \\
\hline $\mathrm{FeO}$ * \\
\hline MgO \\
\hline $\mathrm{CaO}$ \\
\hline $\mathrm{Na}_{2} \mathrm{O}$ \\
\hline$\dot{\mathrm{K}}_{2} \mathrm{O}$ \\
\hline $\mathrm{MnO}$ \\
\hline $\mathrm{TiO}_{2}$ \\
\hline $\mathrm{P}_{2} \mathrm{O}_{5}$ \\
\hline Volatility \\
\hline Total \\
\hline ppm \\
\hline
\end{tabular}

48.6

14.8

10.9

7.8

10.7

2.4

0.50

0.20

1.6

0.4

1.9

48.1

16.0

10.8

7.8

10.1

2.3

0.53

0.21

1. 8

0.4

1. 0

99.8

99.0

$\mathrm{Ba}$

313

450

298

neutron activation

La

$\mathrm{Sm}$

$\mathrm{Yb}$

$\mathrm{Eu}$

Co

$\mathrm{SC}$

$\mathrm{Hf}$

$\mathrm{Th}$

$\mathrm{Tb}$

$\mathrm{Ta}$

21

4.8

20

4.0

4.3

1. 5

45

34

3.4

1.9

0.86

2.3

3.6

1.6

45

34

3.9

1.2

0.86

3.8

*A1l Fe reported as Feo.

Table 2-A Chemical analyses of selected dikes from Class 2 (see Fig. 3) 
Minerals

Plagioclase Pyroxene

olivine

Opaques

Decomposition products

Total
Vol\%

45.5

25.2

6.9

5.4

16.9

99.9

1.8

Table 2-B Modal analysis of member (dike J-16) of Class 2 . Volume percentage of mineral constituents determined from average of two sets of 500 point counts 
$\frac{\mathrm{J}-37}{\text { atomic absorption }}$

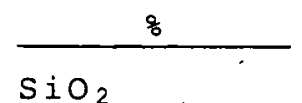

$\mathrm{Al}_{2} \mathrm{O}_{3}$

$\mathrm{FeO}$ *

MgO

$\mathrm{CaO}$

$\mathrm{Na}_{2} \mathrm{O}$

$\mathrm{K}_{2} \mathrm{O}$

$\mathrm{MnO}$

$\mathrm{TiO}_{2}$

$\mathrm{P}_{2} \mathrm{O}_{5}$

Volatility

Total

\section{ppm}

Cr

$\mathrm{Ba}$

La

$\mathrm{Sm}$

$Y b$

$\mathrm{Eu}$

Co

$\mathrm{SC}$

$\mathrm{Hf}$

Th

$\mathrm{Tb}$

$\mathrm{Ta}$

52.1

14.8

10.2

5.8

9. 5

2.7

0.71

0.20

1. 4

0. 2

1. 9

99.5

207

445

101

575

neutron activation

$\begin{array}{cc}14 & 18 \\ 3.6 & 4.1 \\ 3.4 & 3.3 \\ 1.2 & 1.1 \\ 37 & 35 \\ 42 & 40 \\ 3.7 & 3.5 \\ 1.6 & 2.3 \\ 1.0 & 0.92 \\ 1.2 & 2.3\end{array}$

14

3.

$51.9 \cdot \cdots$

14.8

9.5

5.9

9.9

2.8

0.90

0.21

$1: 2$.

0.3

2.4

99.8

*A1l Fe reported as Feo.

Table 3-A Chemical analyses of selected dikes from Class 3 (see Fig. 3) 
Minerals

Plagioclase

Pyroxene.

Olivine

Opaques

Glass + decomposition products

- Total

Plagioclase/pyroxene ratio:
Vol $\%$

48.1

31.0

1.6

6.2

13.0

99.9

1. 5

Table 3-B Modal analysis of member (dike G-7) of class 3. Volume percentage of mineral constituents determined from average of two sets of 500 point counts 


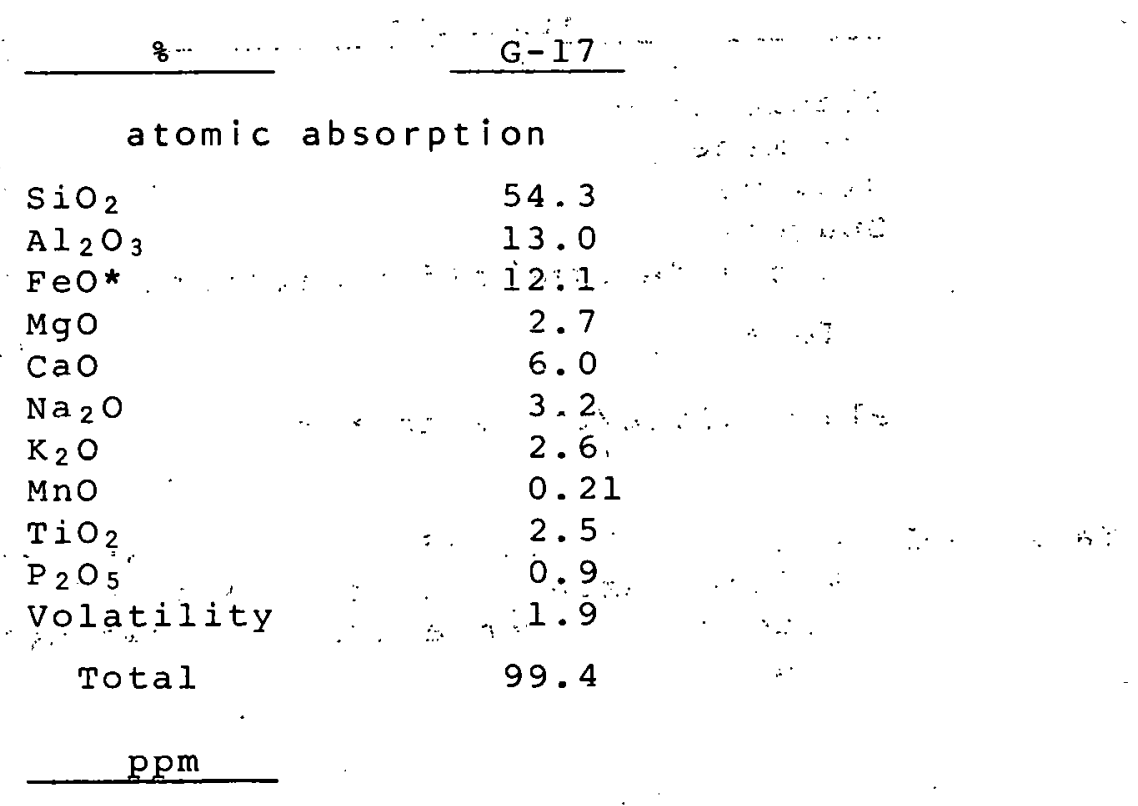

$\begin{array}{lc}\text { Cr } & 3 \\ \text { Ba } & 3403 \\ & \text { neutron activation } \\ \text { La } & 58 \\ \text { Sm } & 10.5 \\ \text { Yb } & 7.6 \\ \text { Eu } & 3.7 \\ \text { Co } & 24 \\ \text { Sc } & 24 \\ \text { Hf } & 12 \\ \text { Th } & 8.0 \\ \text { Tb } & 1.6 \\ \text { Ta } & 3.4 \\ & \end{array}$

Table 4-A Chemical analysis of single member of Class 4 (see Fig. 3) 
Mineral

Plagioclase

Pyroxene

olivine

Opaques

Apatite

Glass

Chlorophaeite

Decomposition products

Total
Vols

41.3

10.2

1. 5

7.2

1.9

$2: 9.3$

4.8

4.1

100.3

4.0

Plagioclase/pyroxene ratio:

6.2

Table 4-B Modal analysis of single dike (dike G-17) of Class 4. Volume percentage of mineral constituents determined from average of two sets of 500 point counts 


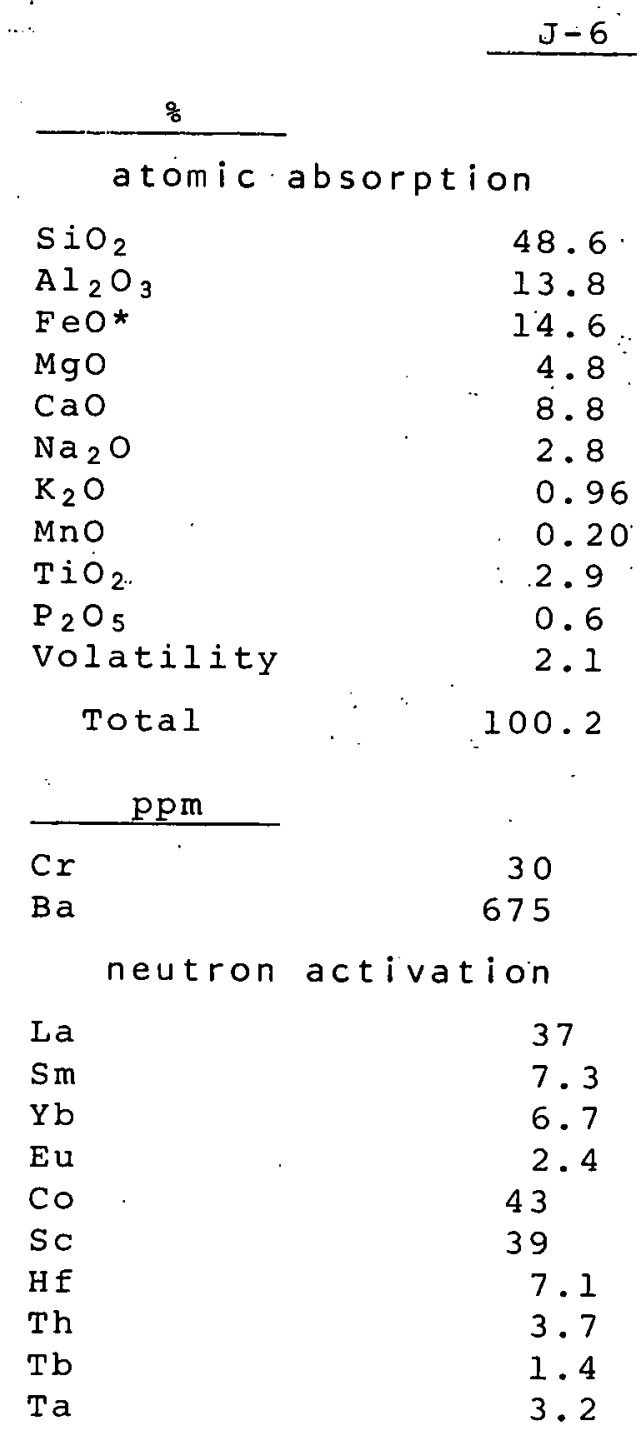

*All Fe reported as Feo.

Table 5-A Chemical analysis of single member of Class 5 (see Fig. 3) 
Mineral

\begin{tabular}{|c|c|c|c|c|}
\hline Plagioclase & & & & 50.0 \\
\hline Pyroxene & & - & & 26.7 \\
\hline Olivine & $\therefore$ & $: \cdot$ & & $\cdot$ \\
\hline Unaltered & & & & 2.4 \\
\hline Altered & & & $\vdots \cdot$ & 4.2 \\
\hline opaques & & & $\cdot$ & 6.9 \\
\hline Apatite & , & & & Trace \\
\hline Decomposition. & products & + & & \\
\hline devitrified & glass & & & 9.2 \\
\hline Total & & & & 99.4 \\
\hline Plagioclase/p & coxene & tio: & & 1.9 \\
\hline
\end{tabular}

Plagioclase

Pyroxene

Unaltered

Atered

lagioclase/pyroxene ratio:

Table 5-B Modal analysis of single member (dike J-6) of Class 5. Volume percentage of mineral constituents determined from two sets of 500 point counts 


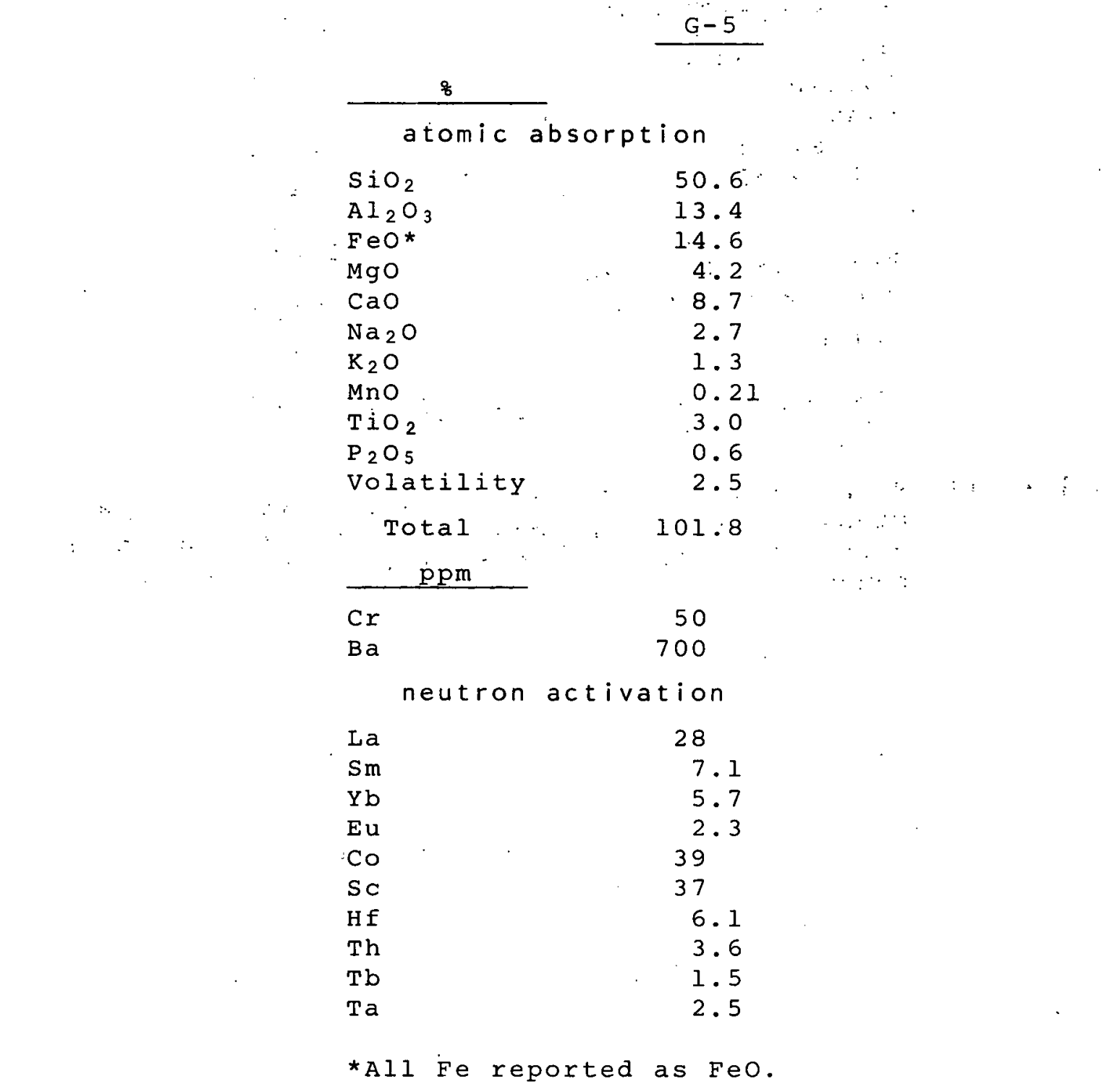

Table 6-A Chemical analysis of single member of Class 6 (see Fig. 3) 
Minerals

Plag
Ph
Mi
Mi
Pyro
Olitv
Glas
To
Plag
loo-
6-B

oclase

Phenocrysts

Microlites

yroxene

olivine

opaque

Total
Microphenocrysts.

lagioclase/pyroxene ratio:
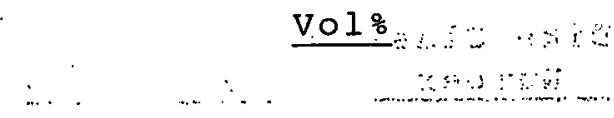

......

2.0

2.6

$: 31.2$

$\therefore 30.6$

1.0

32.5

99.9

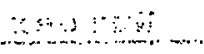

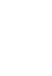

$\therefore \quad$

Table 6

Modal analysis of singlé member (dike G-5) of

Class 6. Volume percentage of mineral constituents determined from average of two sets of 500 point counts. 


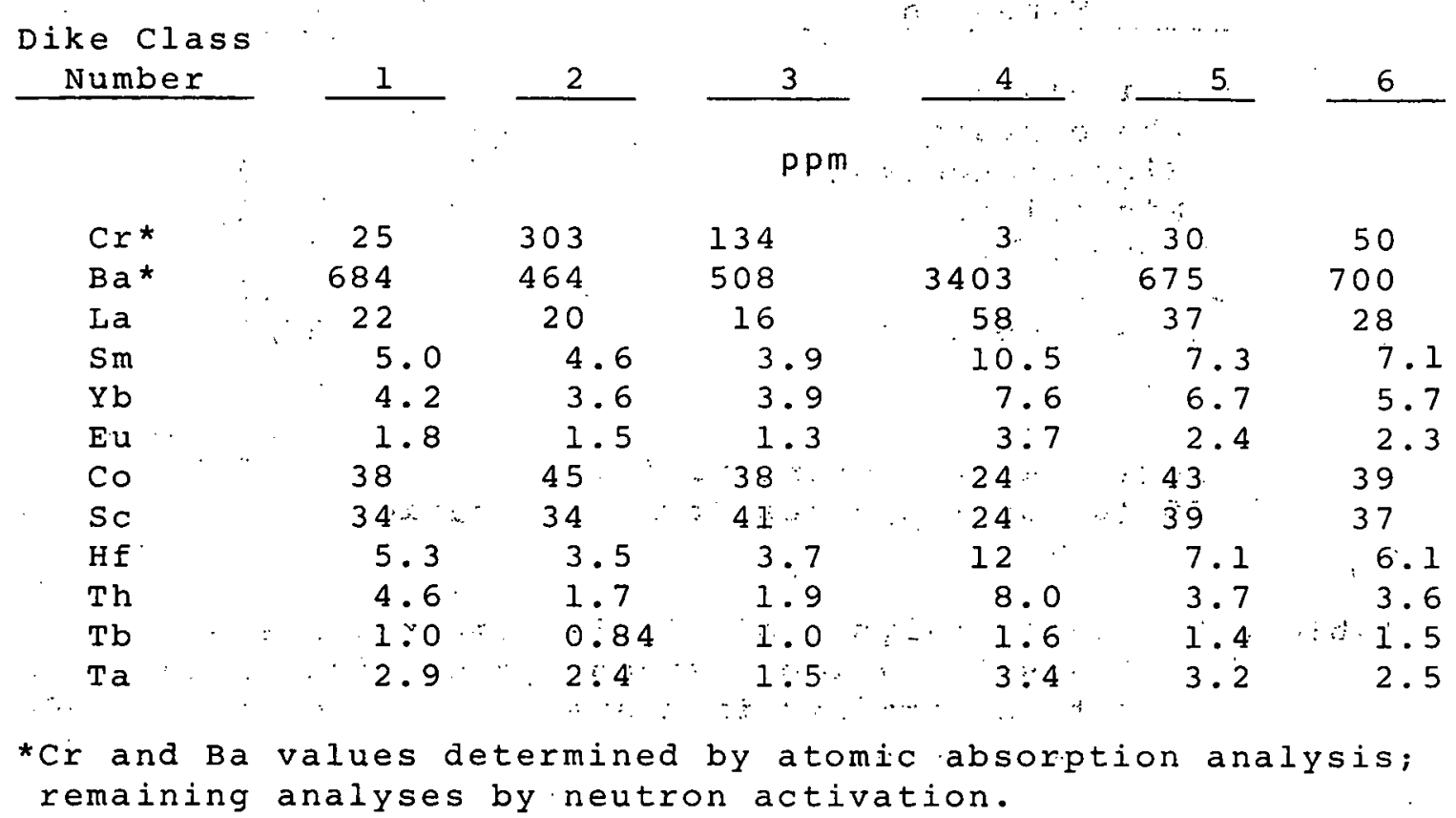

Table 7 Average values of trace element analyses of selected dikes of each class 


\begin{tabular}{|c|c|c|c|c|c|c|c|c|}
\hline \multirow[b]{3}{*}{ Class } & \multirow{2}{*}{\multicolumn{2}{|c|}{ Texture }} & \multicolumn{6}{|c|}{ Mireral Assemblage } \\
\hline & & & \multicolumn{3}{|c|}{$\begin{array}{c}\text { Handspecimen } \\
\text { Pherocryst Percentage }\end{array}$} & \multicolumn{2}{|c|}{ Thin-section } & \multirow{2}{*}{8 Olivine } \\
\hline & Handspecimen & Thin-Section & $\frac{\text { Pnenoct }}{\text { Plagioclase }}$ & St Percer & $\frac{\text { cage }}{\text { olivine }}$ & Plagioclase/Pyroxene & $\begin{array}{l}\text { 10:0-(Glas:stopaques) } \\
\text { Pyroxene. }\end{array}$ & \\
\hline 1 & Fine-grained & Intersertal & Trace & Trace. & Trace & 21.2 & $\sim 2 . .4$ & $<1$ \\
\hline 2 & $\begin{array}{l}\text { Coarse grained, } \\
\text { granular. }\end{array}$ & $\begin{array}{l}\text { Holocrystalline, } \\
\text { diabasic }\end{array}$ & $\leq 10$ & Trace & 210 & 21.8 & & 26 \\
\hline 3 & $\begin{array}{l}\text { Medium- to } \\
\text { coarse-grained, } \\
\text { granular }\end{array}$ & $\begin{array}{l}\text { Hypo- to holo- } \\
\text { crystalline. } \\
\text { ophitic }\end{array}$ & $\leq 10$ & Trace & $\leq 10$ & 21.5 & & $0,1,5$ \\
\hline 4 & $\begin{array}{l}\text { Fine- to } \\
\text { medium-graired }\end{array}$ & Intersertal & Trace & Träace & Trace & $\sim 4.0$ & 26.2 & 21.5 \\
\hline 5 & $\begin{array}{l}\text { Medium-grained, } \\
\text { granular }\end{array}$ & $\begin{array}{l}\text { Holocrystalline; } \\
\text { diabasic }\end{array}$ & $\leq 10$ & Trace. & $\sim 10$ & $21.9^{\circ}$ & & 26 \\
\hline 6 & $\begin{array}{l}\text { Porphyritic, } \\
\text { fine-grained. } \\
\text { matrix. }\end{array}$ & Orthophyric & $\geq 15$ & Trace & Trace. & 21.2 & 22.2 & $\sim 1$ \\
\hline
\end{tabular}

Table 8 Comparison of general petrographic properties of six classes of: dikes 
6 Chemically and petrographically similar to flows comprising Big Butte (Fig. 3). Direct field evidence.

Chemically and petrographically similar to youngest flows capping Shumaker Creek section (Fig. 3) and proximate to Anatone, Washington. Tenable field evidence.

Chemically and petrographically comparable to flow between two major interbeds near top of Buford Creek section (Fig. 3) and to flows comprising Puffer Butte (Fig. 3). Direct field evidence.

Chemically and petrographically similar to porphyritic/diabasic flow or flow sequence capping lower Yakima flows, Buford Creek section (Fig. 3). Tenable field evidence. porphyritic/diabasic flow or flow sequence capping lower Yakima flows, Shumaker Creek section (Fig. 3). Tenable field evidence.

1 Chemically and petrographically comparable to lower Yakima flows. Direct field evidence.

All dikes sampled cross-cut lower basalt formation and appear to be younger.

Flows lying above lower Yakima-middle Yakima contact. (classes 2-6)

\begin{tabular}{l} 
Flows lying above \\
lower basalt-lower \\
Yakima contact \\
\hline Flows lying below \\
lower basalt-lower \\
Yakima contact.
\end{tabular}

* Flows described above lower Yakima-midale Yakima contact not necessarily

listed in stratigraphic order.

Table 9 Relation of dikes of six classes to proximate flows. Field evidence described as "direct" indicates dike(s) of class could be traced to or near point of contact with flow(s). Field evidence rated as "tenable" indicates field evidence supportive of dike-flow relations but could not be utilized as sole evidence of correlation. 


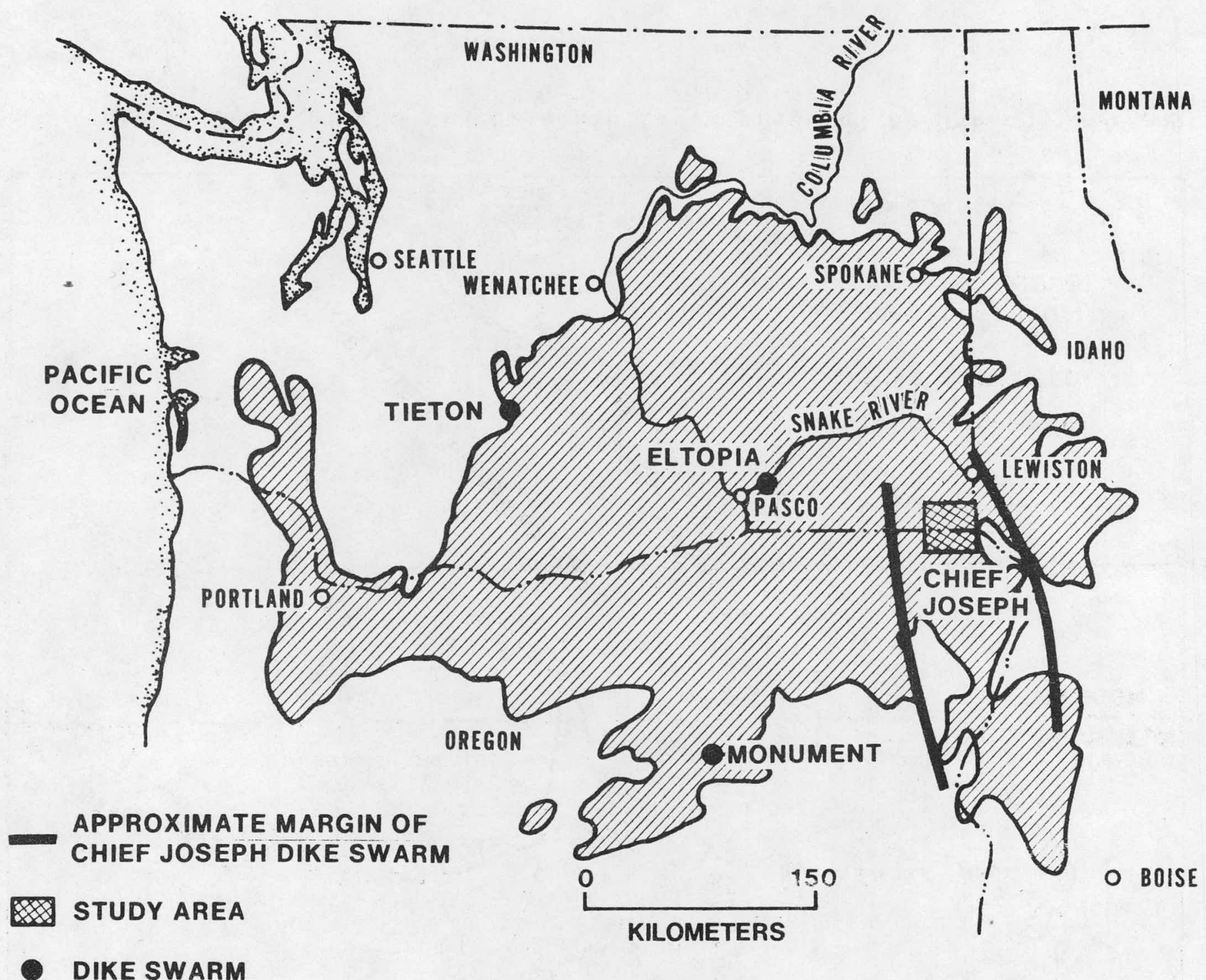




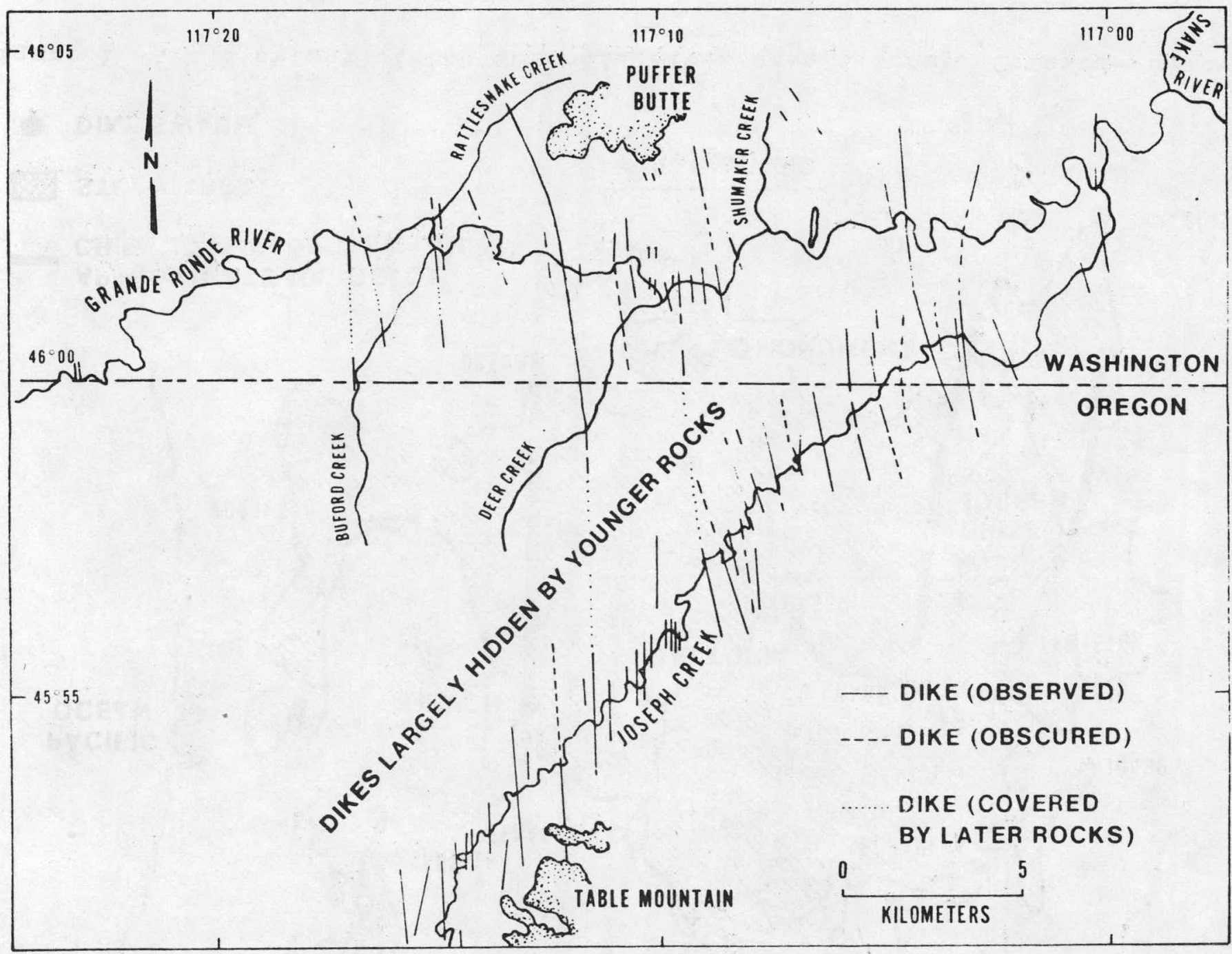

$\sigma$

Figure 2 Map of dikes of the Grande Ronde swarm prepared by Gibson (1969, p. 423) 


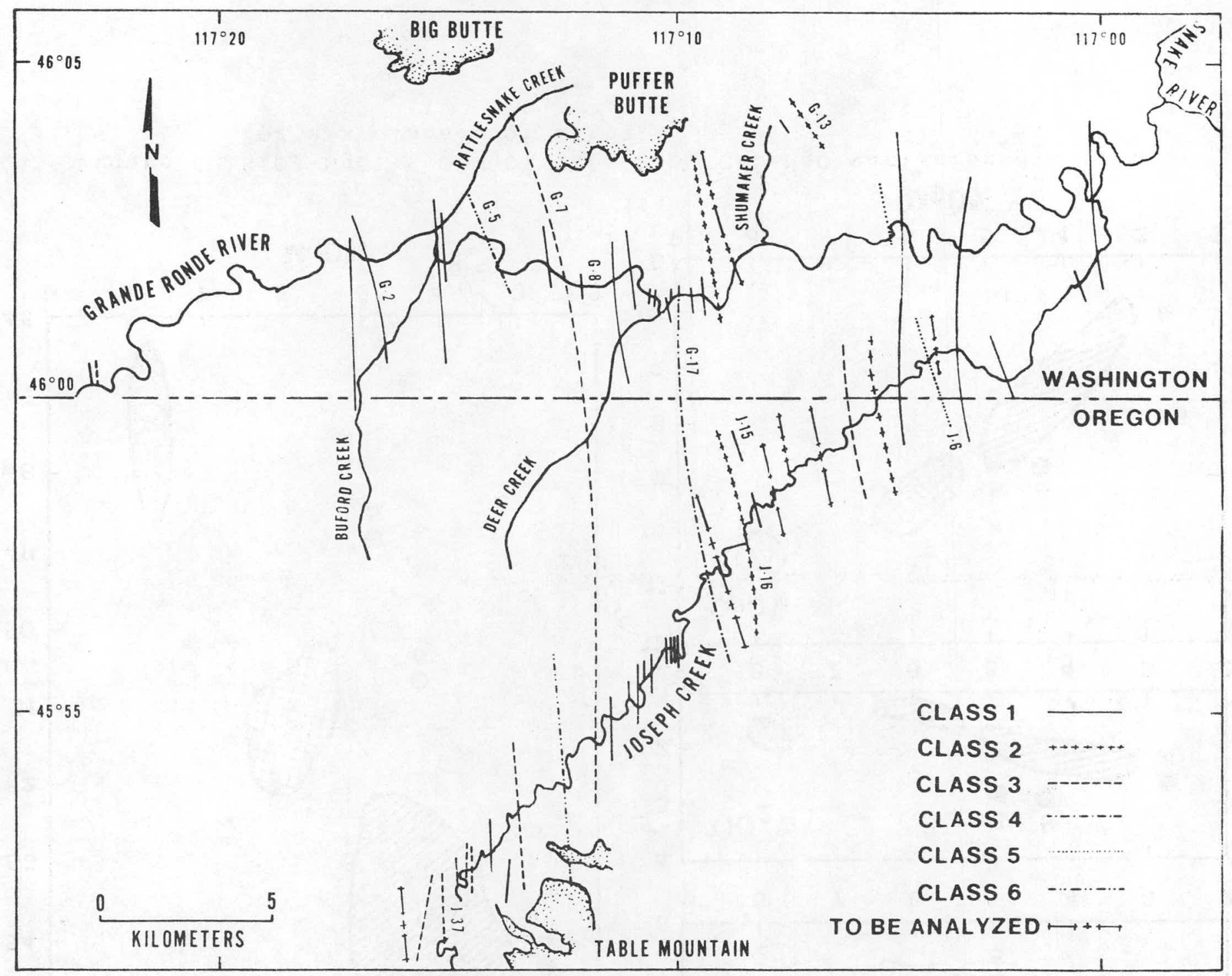

Figure 3 Geochemical classification of dikes of the Grande Ronde swarm (Number adjacent to dike indicates sample designation) 

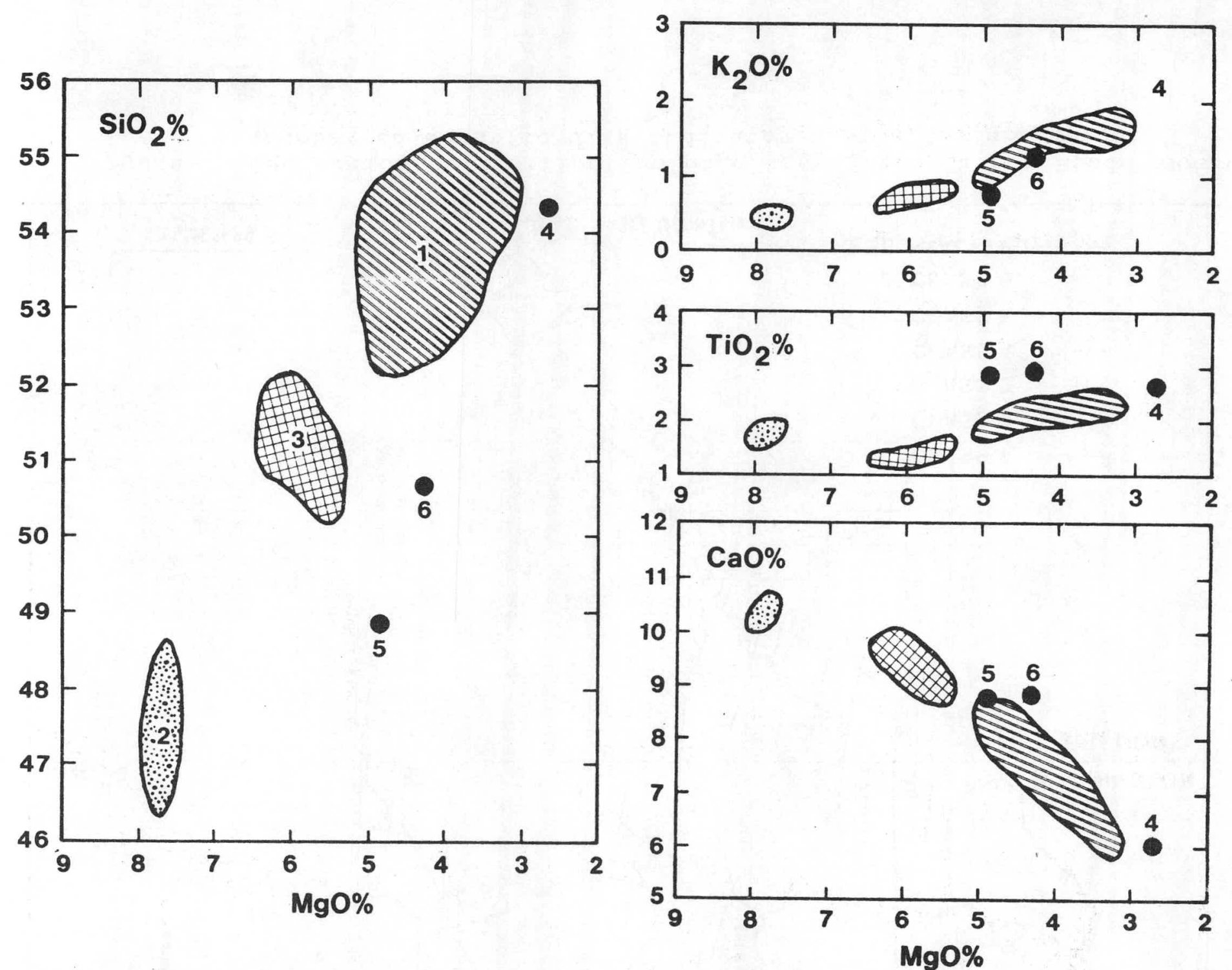

Figure 4 SiOn $-\mathrm{MgO}, \mathrm{K}_{2} \mathrm{O}-\mathrm{MgO}, \mathrm{TiO}_{2}-\mathrm{MgO}$, CaO-MgO variation diagrams for six classes of dikes 


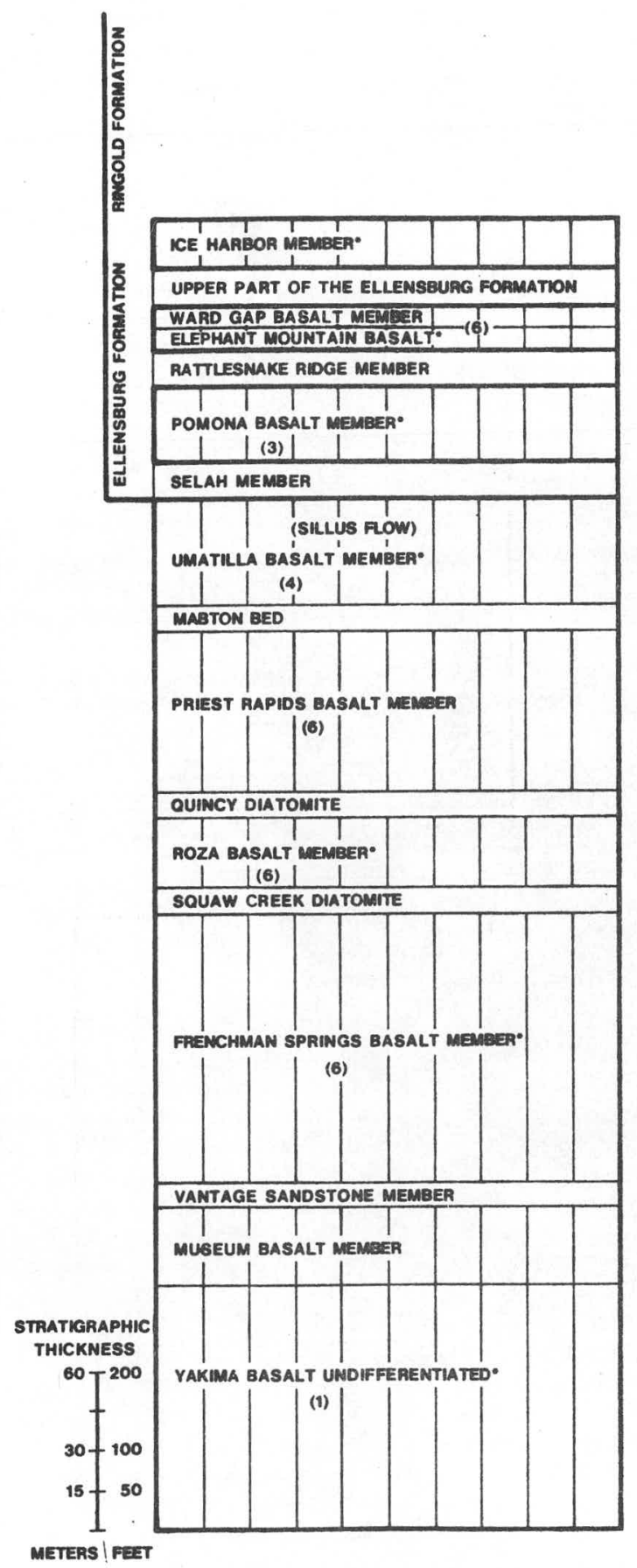

*Analyses of flows used by Wright and others (1973) to determine chemical types.

Figure 5 Type section of Yakima Basalt flows exposed in the region surrounding the Pasco Basin (Brown and Ledgerwood, 1973, p. 178). Numbers adjacent to members designate chemically similar classes of dikes of the Grande Ronde swarm. 